\title{
Use of N-Acetylcysteine in Psychiatric Conditions among Children and Adolescents: A Scoping Review
}

Sadiq Naveed ${ }^{1}$, Afshan Amray ${ }^{2}$, Ahmed Waqas ${ }^{3}$, Amna M. Chaudhary ${ }^{4}$, Muhammad W. Azeem ${ }^{5}$

1. Psychiatry, KVC Hospitals, Kansas 2. Department of Medicine, Dow Medical College, Dow University of Health Sciences 3. Department of Psychiatry, CMH Lahore Medical College and Institute of Dentistry 4. Psychiatry, Nishtar Medical College Hospital, Multan, Pakistan 5. Department of Psychiatry, Sidra Medical and Research Center; Weill Cornell Medical College, Cornell University

$\square$ Corresponding author: Ahmed Waqas, ahmedwaqas1990@hotmail.com Disclosures can be found in Additional Information at the end of the article

\section{Abstract}

$\mathrm{N}$-acetylcysteine (NAC) is a well-known antidote for acetaminophen toxicity and is easily available over the counter. It has antioxidant and anti-inflammatory properties and an established tolerance and safety profile. Owing to its neuroprotective effects, its clinical use has recently expanded to include the treatment of different psychiatric and non-psychiatric disorders. Although a number of randomized controlled trials have documented the clinical evidence for NAC, there are no reviews that summarize the evidence. The present scoping review summarizes the study designs, the patient characteristics, the evidence and the limitations in randomized controlled trials designed to explore the efficacy of NAC for psychiatric conditions in the pediatric population.

Categories: Psychiatry

Keywords: n-actylecysteine, pediatric, children, review, autism, addiction, tourette syndrome, trichotillomania, cannabis, pathological onychophagia

\section{Introduction And Background}

$\mathrm{N}$-acetylcysteine (NAC) has been a well-known antidote for acetaminophen toxicity for the last 30 years [1]. Easily available over the counter, it has antioxidant and anti-inflammatory properties and an established tolerance and safety profile [2-4]. Because of its neuroprotective effects, its clinical use has recently been expanded to include the treatment of different psychiatric and non-psychiatric disorders [1]. The NAC is a synthetic N-acetyl derivative of the

Received 10/08/2017 Review began 11/22/2017 Review ended 11/25/2017 Published 11/29/2017

\section{(C) Copyright 2017}

Naveed et al. This is an open access article distributed under the terms of the Creative Commons Attribution License CC-BY 3.0., which permits unrestricted use, distribution, and reproduction in any medium, provided the original author and source are credited. endogenous amino acid L-cysteine, which is a precursor of the antioxidant enzyme glutathione. The glutathione ( $\mathrm{Y}$-L-glutamyl-L-cysteinyl-glycine) or glutathione (GSH) acts as the body's defense mechanism against the oxidant stress in several metabolic and pathological reactions [4]. It exerts its antioxidant effects by regulating oxidative metabolism and glutamate transmission and plays a rate-limiting role in the synthesis of glutathione, a naturally occurring antioxidant [4-5].

Limited evidence has implicated reactive oxygen species as a culprit in the neuronal dysfunction responsible for several psychiatric and neurodevelopmental conditions [4]. In view of the destructive neuronal effects of reactive oxygen species, the recent research has explored the clinical efficacy of NAC in different neuropsychiatric conditions. The NAC has been found to permeate the blood-brain barrier and has good bioavailability [4]. After intravenous 


\section{Cureus}

administration, the mean elimination half-life of NAC is 5.6 hours in adults and 11 hours in neonates [6]. It exerts its neuronal influence by converting L-cysteine to cysteine, facilitating its uptake by glial cells and consequently allowing the glutamate release, which in turn stimulates inhibitory glutamate receptors [4]. Due to these metabotropic glutamate receptors, there is a reduction in the vesicular release of glutamate, resulting in the decrease in glutamatergic neurotransmission [5]. This mechanism of action of NAC is particularly important because of its effect on glutaminergic neurons in the nucleus accumbens, which is involved in the modulation of the reward and reinforcement center implicated in the addictive behaviors [2].

Several studies have associated the NAC with a reduction in the severity of the symptoms of schizophrenia, bipolar disorders, Alzheimer's, autism and substance abuse (cannabis and cocaine) [6]. In this review, we briefly present recent progress in the use of NAC for different psychiatric disorders in the pediatric population. We also aim to highlight the characteristics of the patient populations, the outcome measures, drug regimens and adverse events reported in the trials reviewed here. Table 1 summarizes the characteristics of the studies we included, the doses of NAC, the results, and the limitations.

\begin{tabular}{|c|c|c|c|c|c|c|c|}
\hline Study & Condition & $\begin{array}{l}\text { Sample } \\
\text { size }\end{array}$ & $\begin{array}{l}\text { Dose of NAC } \\
\text { (mg/day) }\end{array}$ & Duration & Results of study & Limitations & $\begin{array}{l}\text { Adjunct } \\
\text { medications }\end{array}$ \\
\hline $\begin{array}{l}\text { Hardan, et } \\
\text { al. } 2012\end{array}$ & ASD & 33 & $\begin{array}{l}\text { 1st week- } 900 \mathrm{mg} / \text { day } \\
2 \mathrm{nd} \text { week - } 1800 \mathrm{mg} / \text { day } \\
\text { 3rd week- } 2700 \mathrm{mg} \text { three } \\
\text { times a day }\end{array}$ & $\begin{array}{l}12 \\
\text { weeks }\end{array}$ & $\begin{array}{l}\text { Improvement in irritability } \\
\text { with NAC. Decreased } \\
\text { episodes of } \\
\text { repetitive/stereotype } \\
\text { behavior }\end{array}$ & $\begin{array}{l}\text { Small sample } \\
\text { size } \\
\text { Concomitant } \\
\text { use of } \\
\text { psychotropic } \\
\text { medications } \\
\text { and behavioral } \\
\text { interventions }\end{array}$ & $\begin{array}{l}\text { Use of } \\
\text { medications, most } \\
\text { commonly 2nd } \\
\text { generation } \\
\text { antipsychotics } \\
\text { and SSRls }\end{array}$ \\
\hline $\begin{array}{l}\text { Ghanizadeh } \\
\text { \& Moghimi- } \\
\text { Sarani } 2013\end{array}$ & ASD & 40 & $1200 \mathrm{mg}$ & 8 weeks & $\begin{array}{l}\text { Improvement in irritability } \\
\text { with NAC \& Risperidone }\end{array}$ & $\begin{array}{l}\text { Small Sample } \\
\text { size Short } \\
\text { duration Low } \\
\text { dose of NAC }\end{array}$ & $\begin{array}{l}\text { Medications with } \\
\text { glutamatergic } \\
\text { effects was not } \\
\text { allowed Stable } \\
\text { doses of other } \\
\text { medications }\end{array}$ \\
\hline $\begin{array}{l}\text { Nikoo, et al. } \\
2015\end{array}$ & ASD & 40 & $\begin{array}{l}\text { Dose of risperidone was } \\
\text { from } 1 \text { and } 2.0 \mathrm{mg} / \mathrm{d} \text {, and } \\
\text { the dose of NAC was } 600 \\
\text { to } 900 \mathrm{mg} / \mathrm{d}\end{array}$ & $\begin{array}{l}10 \\
\text { weeks }\end{array}$ & $\begin{array}{l}\text { The significant reduction in } \\
\text { irritability with NAC \& } \\
\text { Risperidone. Lack of } \\
\text { improvement in } \\
\text { lethargy/social withdrawal } \\
\text { subscale. No improvement in } \\
\text { stereotypic behaviors. } \\
\text { Reduction in hyperactivity } \\
\text { and non-compliance. No } \\
\text { improvement in inappropriate } \\
\text { speech }\end{array}$ & $\begin{array}{l}\text { Short duration } \\
\text { of study Small } \\
\text { sample size }\end{array}$ & $\begin{array}{l}\text { Taking } \\
\text { concomitant } \\
\text { medications with } \\
\text { glutamatergic } \\
\text { effects were not } \\
\text { allowed }\end{array}$ \\
\hline & & & Dose of NAC was 300- & & $\begin{array}{l}\text { No improvement in social } \\
\text { impairment. } \\
\text { No difference in GSH/GSSG }\end{array}$ & $\begin{array}{l}\text { High attrition } \\
\text { rates Small }\end{array}$ & $\begin{array}{l}\text { Stimulants, alpha- } \\
2 \text { agonist, } \\
\text { antipsychotics, }\end{array}$ \\
\hline
\end{tabular}




\section{Cureus}

\begin{tabular}{|c|c|c|c|c|c|c|c|}
\hline $\begin{array}{l}\text { Wink, et al. } \\
2016\end{array}$ & ASD & 31 & $\begin{array}{l}600 \mathrm{mg} / \text { daily target dose } \\
\text { of } 60 \mathrm{mg} / \mathrm{kg} / \mathrm{day} \text {, } \\
\text { reaching to } 4200 \mathrm{mg} / \text { day }\end{array}$ & $\begin{array}{l}12 \\
\text { weeks }\end{array}$ & $\begin{array}{l}\text { ratio, strand break, oxidative } \\
\text { damage of } \\
\text { deoxyribonucleic acid (DNA), } \\
\text { and blood homocysteine } \\
\text { between both groups }\end{array}$ & $\begin{array}{l}\text { sample size. } \\
\text { Higher IQ in } \\
\text { majority of } \\
\text { participants }\end{array}$ & $\begin{array}{l}\text { sleep aids, } \\
\text { antidepressants, } \\
\text { anti-epileptic } \\
\text { medications }\end{array}$ \\
\hline $\begin{array}{l}\text { Dean, et al. } \\
2016\end{array}$ & ASD & 102 & $500 \mathrm{mg}$ & $\begin{array}{l}6 \\
\text { months }\end{array}$ & $\begin{array}{l}\text { No significant improvement } \\
\text { were found on the primary } \\
\text { outcomes of communication, } \\
\text { social interaction, repetitive } \\
\text { behaviors and parent/clinical } \\
\text { global impression }\end{array}$ & $\begin{array}{l}\text { Low dose of } \\
\text { NAC. High } \\
\text { attrition rates }\end{array}$ & \\
\hline $\begin{array}{l}\text { Bloch, et al. } \\
2013\end{array}$ & Trichotillomania & 39 & $\begin{array}{l}600 \mathrm{mg} \text { at dinner for one } \\
\text { week, then } 600 \mathrm{mg} \text { twice } \\
\text { a day for one week, then } \\
600 \mathrm{mg} \text { in the morning } \\
\text { and at dinner for one } \\
\text { week, and then remained } \\
\text { on a dose of } 1200 \mathrm{mg} \\
\text { twice a day for the } \\
\text { remainder of the } 12- \\
\text { week study }\end{array}$ & $\begin{array}{l}12 \\
\text { weeks }\end{array}$ & $\begin{array}{l}\text { No significant changes in } \\
\text { hair-pulling severity were } \\
\text { reported over the follow-up } \\
\text { period }\end{array}$ & $\begin{array}{l}\text { Strong } \\
\text { possibility of } \\
\text { Type I and II } \\
\text { error without } \\
\text { appropriate } \\
\text { statistical } \\
\text { correction }\end{array}$ & $\begin{array}{l}\text { SSRIs, } \\
\text { antipsychotics, } \\
\text { psychostimulants, } \\
\text { and atomoxetine }\end{array}$ \\
\hline $\begin{array}{l}\text { Ghanizadeh, } \\
\text { et al. } 2013\end{array}$ & Nail biting & 42 & $800 \mathrm{mg} /$ day & $\begin{array}{l}2 \\
\text { months }\end{array}$ & $\begin{array}{l}\text { Lack of improvement in nail- } \\
\text { biting }\end{array}$ & $\begin{array}{l}\text { Higher rates of } \\
\text { loss to follow- } \\
\text { up. Psychiatric } \\
\text { comorbidity } \\
\text { lower doses of } \\
\text { NAC shorter } \\
\text { duration of } \\
\text { exposure }\end{array}$ & $\begin{array}{l}\text { Were allowed to } \\
\text { continue } \\
\text { medications. } \\
\text { Detail was not } \\
\text { mentioned }\end{array}$ \\
\hline $\begin{array}{l}\text { Bloch, et al. } \\
2016\end{array}$ & $\begin{array}{l}\text { Tourette } \\
\text { syndrome }\end{array}$ & 39 & $2400 \mathrm{mg}$ & $\begin{array}{l}12 \\
\text { weeks }\end{array}$ & $\begin{array}{l}\text { No significant difference } \\
\text { between NAC and placebo } \\
\text { in reducing tics }\end{array}$ & $\begin{array}{l}\text { Inadequate } \\
\text { assessment of } \\
\text { compliance. } \\
\quad \text { Difference in } \\
\text { the severity of } \\
\text { anxiety at } \\
\text { baseline } \\
\text { between } \\
\text { placebo and } \\
\text { intervention } \\
\text { group }\end{array}$ & $\begin{array}{l}\text { Antidepressants, } \\
\text { stimulants, } \\
\text { antipsychotics } \\
\text { and alpha } 2 \\
\text { agonists }\end{array}$ \\
\hline $\begin{array}{l}\text { Grey, et al. } \\
2012\end{array}$ & Cannabis use & 116 & $2400 \mathrm{mg}$ & 8 weeks & $\begin{array}{l}\text { Weekly negative urinary } \\
\text { cannabinoid tests shows } \\
\text { the beneficial effect of NAC. } \\
\text { Improvement in self-reported } \\
\text { days of cannabis use and } \\
\text { craving favored NAC, though } \\
\text { without reaching statistical } \\
\text { significance }\end{array}$ & $\begin{array}{l}\text { Short duration. } \\
\text { Single site study }\end{array}$ & Not mentioned \\
\hline
\end{tabular}




\section{Cureus}

\begin{tabular}{|c|c|c|c|c|c|c|c|}
\hline $\begin{array}{l}\text { Roten, et al. } \\
2013\end{array}$ & $\begin{array}{l}\text { Cannabis- } \\
\text { related } \\
\text { cravings }\end{array}$ & 89 & $2400 \mathrm{mg}$ & 8 weeks & $\begin{array}{l}\text { A significant improvement in } \\
\text { marijuana craving } \\
\text { questionnaire scores over the } \\
\text { course of the treatment, } \\
\text { there was no significant } \\
\text { differential change between } \\
\text { the NAC and placebo groups }\end{array}$ & $\begin{array}{l}\text { MCQ was } \\
\text { validated in } \\
\text { adult non- } \\
\text { treatment } \\
\text { seekers but it } \\
\text { was used to } \\
\text { measure } \\
\text { craving in our } \\
\text { study in } \\
\text { adolescent } \\
\text { treatment } \\
\text { seekers }\end{array}$ & Not mentioned \\
\hline $\begin{array}{l}\text { Roten, et al. } \\
2015\end{array}$ & $\begin{array}{l}\text { Neurocognitive } \\
\text { performance in } \\
\text { cannabis users }\end{array}$ & 78 & $2400 \mathrm{mg}$ & 8 weeks & $\begin{array}{l}\text { Significant improvement in } \\
\text { cognition like verbal memory, } \\
\text { composite memory and } \\
\text { psychomotor performance } \\
\text { with NAC }\end{array}$ & $\begin{array}{l}\text { Less power to } \\
\text { detect } \\
\text { differences. The } \\
\text { absence of data } \\
\text { about cognitive } \\
\text { performance } \\
\text { prior to using } \\
\text { marijuana. } \\
\text { Absence of } \\
\text { non-marijuana } \\
\text { using controls }\end{array}$ & Not mentioned \\
\hline $\begin{array}{l}\text { McClure, et } \\
\text { al. } 2014\end{array}$ & $\begin{array}{l}\text { Smoking } \\
\text { cessation in } \\
\text { cannabis users }\end{array}$ & 116 & $2400 \mathrm{mg}$ & 8 weeks & $\begin{array}{l}\text { No change in cigarettes per } \\
\text { day for either NAC or placebo } \\
\text { groups }\end{array}$ & $\begin{array}{l}\text { High attrition } \\
\text { rates Smoking } \\
\text { cessation was } \\
\text { not primary } \\
\text { outcome }\end{array}$ & Not mentioned \\
\hline
\end{tabular}

TABLE 1: Summary of the sample sizes, doses of $\mathrm{N}$-acetylcysteine, results, and the limitation of randomized controlled trials.

ASD: Autism spectrum disorder, NAC: N-acetylcysteine, MCQ: Marijuanna Craving Questionnaire, SSRI: selective serotonin reuptake inhibitors.

\section{Review}

\section{Autism spectrum disorder}

Oxidative stress due to glutathione deficiency has been hypothesized to be a potential causal factor in the pathogenesis of autism spectrum disorder (ASD) [5]. The glutathione has also been linked to the frequent gastrointestinal and immunological dysfunctions in the people with autistic disorder [5]. Therefore, the NAC can serve as a potential treatment option because of its important rate-limiting role in glutathione metabolism.

A search in PubMed with the search strategy ("N-acetylcysteine" or "NAC" and "autism") yielded five randomized controlled trials (RCTs). In a double-blind randomized controlled trial by Hardan, et al. (2012), the efficacy of the oral NAC was assessed in physically healthy 
males and females aged three to 12 years with ASD, between March 2009 and September 2010 [5]. The primary outcome measures were the Aberrant Behavior Checklist (ABC) score to assess irritability and the Dosage Record Treatment Emergent Symptom (DOTES) scale score to record the severity of the side effects [5]. The participants were randomized to the NAC treatment $(n=14)$ or a placebo group $(n=15)$ in a 12 -week double-blind RCT. The initial dose of NAC was $900 \mathrm{mg}$ per day for the first four weeks, which was increased to $900 \mathrm{mg}$ twice daily for the next four weeks, and $900 \mathrm{mg}$ three times per day for the following four weeks. The clinical evaluation was done at the baseline and at weeks four, eight, and 12. This study reported a significant improvement in irritability in the NAC group, manifested as a lower ABC irritability subscale score and a decrease in the number of repetitive/stereotyped behaviors (Cohen's $d=0.96$ ) [5]. Although this RCT was statistically underpowered, the authors reported low bias related to randomization, allocation concealment, attrition and blinding of the participants and personnel toward the outcome assessment. There was no statistically significant difference between the placebo and intervention groups in the frequency of the side effects.

Ghanizadeh \& Moghimi-Sarani (2013) studied the efficacy of the NAC as an adjuvant in children and adolescents with autism who were treated with risperidone to decrease irritability in an eight-week double-blind RCT. The participants of both genders aged between 3.5 to 16 years were recruited from the outpatient psychiatry clinics if they had no concomitant medication prior to the enrollment. The intervention group received a combination of risperidone and NAC (1200 mg/day) in two divided doses, while the control group received a placebo with risperidone. The initial dose of risperidone was $0.5 \mathrm{mg} /$ day and was gradually titrated to $2 \mathrm{mg} /$ day for the participants weighing less than $30 \mathrm{~kg}$ and $3 \mathrm{mg}$ daily for those weighing $>30 \mathrm{~kg}$. The change in the ABC irritability subscale score was the primary outcome measure. This study suggested that the use of the NAC as an oral supplement and adjuvant to the current treatment for irritability was superior to the combination of risperidone and placebo (effect size $=1.4$ ). Mild adverse effects were constipation, increased appetite, fatigue, nervousness and daytime sleepiness [6]. There was low bias related to randomization, allocation concealment and blinding of the patients, parents, and assessors, but this study too was underpowered and had attrition bias.

The effectiveness of the NAC as an adjunct to risperidone was assessed in another randomized, double-blind, controlled trial [7]. The irritability was assessed with the ABC irritability subscale in 40 children (after attrition) who were randomized to receive risperidone plus NAC or risperidone plus placebo. The secondary outcome measures included the social withdrawal, stereotypic behaviors, hyperactivity and inappropriate speech. The patients in both groups received risperidone at an initial dose of $0.5 \mathrm{mg}$ with stepwise titration of $0.5 \mathrm{mg} / \mathrm{week}$ for the first three weeks. The maximum dose of risperidone was $1 \mathrm{mg} /$ day for children weighing less than $20 \mathrm{~kg}$ and $2 \mathrm{mg} /$ day for those weighing $\geqslant 20 \mathrm{~kg}$. The intervention group received 600 to 900 $\mathrm{mg}$ /day of NAC in three divided doses of $200 \mathrm{mg} /$ dose for children weighing < $20 \mathrm{~kg}$ and 300 $\mathrm{mg} /$ day for those weighing $\geqslant 20 \mathrm{~kg}$. The $\mathrm{N}$-acetylcysteine was effective in improving irritability compared to the placebo in this study (Cohen's $d=1.06$ ). In addition, the hyperactivity/noncompliance improved significantly in the intervention group compared to the placebo group. The side-effect profile was mild and transient, with no substantial differences between the intervention and placebo groups [7]. This study had a low risk of bias related to randomization, allocation concealment and blinding of the participants and the study personnel. However, significant bias was likely because of low statistical power and attrition bias.

Wink, et al. (2016) designed a double-blind, placebo-controlled RCT to assess the effectiveness of the NAC in improving social communication in the patients with autism. The participants were children between the ages of four to 12 years who weighed $\geqslant 15 \mathrm{~kg}$, and who had a confirmed diagnosis of the autism, Asperger's disorder or pervasive developmental disorder not otherwise specified. All were judged to be moderately ill based on the Clinical Global 
Impression severity (CGI-S) subscale. The participants were allowed to take their concomitant medications except for glutaminergic pathway modulators [4]. The patients were prescribed a formulation of the NAC containing 300-600 mg in divided doses, with a daily target dose of 60 $\mathrm{mg} / \mathrm{kg}$ and a maximum dose of $4200 \mathrm{mg} /$ day. The participants who weighed 15-30 kg were started on $300 \mathrm{mg} / \mathrm{day}$, and those who weighed more than $30 \mathrm{~kg}$ were started on $600 \mathrm{mg} / \mathrm{day}$. The initial dose was continued for the first three weeks and then gradually increased and continued for the nine-week study period. The primary outcome measure was social impairment according to the CGI improvement (CGI-I) subscale. This study found no significant improvement in the social impairment in children with autism who were treated with the NAC compared to the placebo, although a marginally significant improvement was seen at week eight with a P value of 0.07 [4]. This study also investigated the impact of NAC on oxidative stress markers in peripheral and venous blood samples collected at baseline and week 12. The glutathione (Cohen's d=0.64) and glutathione disulfide (GSSG) (Cohen's $d=0.88$ ) improved more in the intervention group than the placebo group. However, there was no difference between groups in GSH/GSSG ratio, strand breaks, DNA oxidative damage or blood homocysteine concentration [4]. A low risk was reported in connection with randomization, allocation concealment and or blinding of the patients, parents, and personnel, but the study was biased due to attrition and beta error.

Another placebo-controlled RCT assessed the efficacy of the NAC for core symptoms of ASD as the primary outcome measure. The outcomes were assessed with the Social Responsiveness Scale, Children's Communication Checklist (second edition), and the Repetitive Behavior ScaleRevised. A total of 102 children was allocated to the NAC or placebo group, and a dose of 500 $\mathrm{mg} /$ day for six months were used in the NAC group. This trial failed to show a statistically significant benefit of the NAC in the management of core symptoms of the ASD. The side-effect profile was similar in both the intervention and placebo groups [8]. The study had low statistical power and a high rate of attrition, but there was the low risk of bias in randomization, allocation concealment, and blinding of the patients and research personnel.

\section{Trichotillomania}

Trichotillomania is an impulse control disorder characterized by the chronic hair-pulling, distress and functional impairment [9]. The hair-pulling, which can occur in any area of the body where hair grows, most commonly involves the scalp followed by the eyelashes and eyebrows [10]. There is limited evidence for the effectiveness of the NAC treatment in pediatric and adult populations, and the results published to date have been mixed [11-14]. However, one study found that the NAC decreased the extracellular concentration of the glutamate in the nucleus accumbens, reducing the symptoms of compulsive behaviors such as trichotillomania [15].

A PubMed search with keywords ("N-acetyl cysteine" or "NAC" and "trichotillomania") yielded 14 articles including one RCT that met our inclusion criteria. A double-blind, placebocontrolled trial by Bloch and colleagues enrolled 39 children and young adults and found no significant difference in the reduction of hair-pulling between the NAC and placebo groups [13]. In view of the mixed results, larger RCTs are needed to assess the effectiveness of the NAC for treating trichotillomania.

\section{Pathological onychophagia}

Onychophagia, a behavioral disorder in the children and young adults, is characterized by a compulsion leading to habitual nail-biting. By the age of 18 years, the frequency of this behavior decreases, but it may persist in some adults. It is an under-recognized problem with a three-month prevalence of $22.3 \%$ in the males and females [16]. The pharmacological options to treat nail-biting or onychophagia are limited [16]. Using the keywords ("N-acetylcysteine" or 
"NAC" and "onychophagia"), we were able to identify one suitable RCT out of six search entries in the PubMed.

There is limited evidence for the efficacy of the NAC in onychophagia. A study by Ghanizadeh, et al. (2013) explored the efficacy of the NAC in the treatment of nail-biting in a two-month double-blind, placebo-controlled trial [16]. This study recruited 25 children and adolescents aged six to 18 years, with a history of chronic nail-biting that caused emotional distress and physical damage but without serious medical illness. Concomitant medications were allowed during the trial, and participants were informed about the primary outcome and requested not to cut their nails. In the NAC group, nine children received concurrent medication, including citalopram, fluoxetine, nortriptyline, methylphenidate, risperidone, and atomoxetine. The Nacetylcysteine was given at the dose of $800 \mathrm{mg} /$ day with an initial dose of $200 \mathrm{mg} / \mathrm{day}$. The outcome measure was the length of all nails in millimeters, measured twice in each session. A headache and aggressive behavior were the most common adverse effects in the NAC group. This study suggested that nail length increased more gradually in the NAC treatment group compared to the placebo group during the first month, but no significant difference was found in a follow-up assessment after two months. The N-acetylcysteine was thus found to be effective in improving impulsiveness in nail-biting for a short period [16]. The study had low power and high risk associated with attrition, but was double-blinded and randomized, and had low risk associated with allocation concealment. It also had a few limitations: a) high levels of psychiatric comorbidity, (b) low doses of NAC administered, and (c) short duration of the treatment. Due to its very small sample size, no cause-effect relationship related to the adverse effects of medication could be inferred from this study.

\section{Pediatric Tourette syndrome}

Tourette syndrome is a chronic disorder that starts in childhood and is characterized by motor and vocal tics of variable frequency, persisting for more than one year [9]. It is often associated with behavioral disorders, particularly obsessive-compulsive disorder (OCD) and attention deficit hyperactivity disorder (ADHD). The PubMed searches with the keywords ("Nacetylcysteine" or "NAC" and “Tourette”) yielded one suitable RCT for inclusion out of eight entries.

Considering the potential evidence in the spectrum of OCD, Bloch, and colleagues (2016) studied the effectiveness of the NAC for the management of the pediatric Tourette syndrome in a double-blind, placebo-controlled trial [3]. In their study, 31 children and adolescents aged eight to 17 years were randomly allocated to receive NAC or a placebo for 12 weeks [3]. A significant proportion of the participants had a comorbid disorder such as OCD and ADHD and were receiving concurrent treatments such as psychological therapy, antidepressants, stimulants, antipsychotics and alpha- 2 agonists. The primary outcome measures were the Yale Global Tic Severity Scale (YGTSS) score and the Total tic score. There was no significant difference between the NAC and placebo groups in the reduction of tic severity [3]. Like previously reported studies, this study was underpowered; however, other methodological characteristics were of adequate quality. A headache was the only adverse effect, reported by one participant in the NAC group. Inadequate assessment of compliance and differences between the placebo and intervention groups in the severity of anxiety at baseline were major limitations in this study.

\section{Cannabis use disorder}

Substance use disorder is defined as the recurrent use of alcohol and/or drugs that can cause functional impairment such as health problems, disability, and failure to meet major responsibilities at work, school or home. According to the Diagnostic and Statistical Manual of Mental Disorders (DSM)-5, a diagnosis of substance use disorder is based on evidence of 
impaired control, social impairment, risky use and pharmacological criteria [9].

A PubMed search with the keywords ("N-acetyl cysteine" and "cannabis") yielded 13 articles, including four that met our inclusion criteria. The efficacy of NAC as a pro-drug for cannabis use disorder and nicotine use disorder was studied in one clinical trial [2]. In this large doubleblind randomized trial, Gray, et al. administered $2400 \mathrm{mg}$ /day of NAC or placebo for eight weeks with 116 participants between 15 and 21 years old who were addicted to marijuana [2]. Both groups also received a contingency management intervention and cessation counseling. Significantly more participants in the NAC treatment group had a negative urine cannabinoid test [2]. The measures of self-reported days of cannabis use and craving favored NAC, although the differences compared to the placebo group did not reach statistical significance [2]. The significant improvements in cognitive performance were seen in the early stages of the treatment-associated abstinence [2].

Roten, et al. studied the role of NAC in controlling cravings in the patients who were dependent on cannabis [17]. The participants in this double-blind RCT had a history of cannabis dependence and were between 15 and 21 years old. All participants were given oral NAC at 1200 mg twice per day or a placebo for eight weeks and also received cessation counseling for less than 10 min with the management intervention [17]. The Marijuana Craving Questionnaire (MCQ) was used to assess cravings. This study did not find a decrease in marijuana craving in the NAC treatment group compared to the placebo group [17]. In part of this study published as a separate article, the role of NAC in improving cognitive performance was analyzed [18]. All participants completed a cognitive task performance test and the computer-administered computerized neurocognitive (CNS) vital signs battery test at baseline on their first appointment and in weeks four and eight during the trial were done. The authors found significant improvements in cognitive tasks such as verbal memory and psychomotor speed within weeks of marijuana cessation [18]. Further analyses of data from this trial found that the NAC treatment was associated with increased rates of abstinence in the individuals seeking treatment for cannabis use disorder, although positive correlations were also found with low impulsivity, high medication adherence, and negative urine cannabinoid test findings at baseline [18].

The co-occurrence of cannabis and tobacco use is highly prevalent and is a major public health issue. The clinical role of the NAC to treat nicotine use disorder was investigated in the patients with a history of cannabis use [19]. This study recruited 116 participants, 15 to 21 years old, who used cannabis regularly (> three days/week) and showed interest in the cannabis cessation treatment [19]. The participants were allocated to the NAC or placebo group, and the dose of NAC was $1200 \mathrm{mg}$ twice per day with a matched placebo. The treatment continued for eight weeks, and follow-up appointments were held in 12 weeks. The clinical assessment was based on urine samples and the number of cigarettes per day [19]. This study suggested a decrease in urges/craving to smoke cigarettes and cannabis but did not find a reduction in the number of cigarettes smoked per day in either group.

\section{Conclusions}

Because of its antioxidant and glutamate modulating properties, the NAC has become a focus of interest in recent studies designed to investigate the treatment options for the core symptoms of ASD and comorbid irritability. Although the evidence available to date for its therapeutic activity is marred by low statistical power, the NAC may be a potential treatment option as an adjunct to antipsychotics in efforts to improve symptoms of irritability. Recent RCTs has yielded mixed results for different outcomes, but these studies were limited by their small sample sizes, short duration, different formulations of NAC, and different dosage regimens.

The children with ASD constitute a heterogeneous group of the patients with a range of 
strengths and challenges that impact the efficacy of the treatment. A few RCTs have reported improvements in repetitive or stereotyped behaviors, lethargy, and social withdrawal in addition to improvements in irritability. However, these results have generally not been replicated in other studies. Future research should be conducted with appropriate doses of NAC and longer follow-up periods to better document its potential benefits for the core treatment of ASD. The N-Acetylcysteine was ineffective for the treatment of trichotillomania, habitual nailbiting and pediatric Tourette syndrome. On the other hand, it has been tested for cannabis use disorder and smoking cessation with favorable results. However, the clinicians should carefully consider the benefits, risk factors and alternatives when recommending NAC as a treatment option. The findings of the RCTs reviewed here need to be validated by carefully planned studies with adequate sample sizes.

\section{Additional Information}

\section{Disclosures}

Conflicts of interest: In compliance with the ICMJE uniform disclosure form, all authors declare the following: Payment/services info: All authors have declared that no financial support was received from any organization for the submitted work. Financial relationships: All authors have declared that they have no financial relationships at present or within the previous three years with any organizations that might have an interest in the submitted work. Other relationships: All authors have declared that there are no other relationships or activities that could appear to have influenced the submitted work.

\section{Acknowledgements}

We thank Ms. Karen Shashok (AuthorAID in the Eastern Mediterranean) for the language improvement in the manuscript.

\section{References}

1. Scalley RD, Conner CS: Acetaminophen poisoning: a case report of the use of acetylcysteine . Am J Health Syst Pharm. 1978, 35:964-7.

2. Gray KM, Carpenter MJ, Baker NL, et al.: A double-blind randomized controlled trial of Nacetylcysteine in cannabis-dependent adolescents. Am J Psychiatry. 2012, 169:805-12. 10.1176/appi.ajp.2012.12010055

3. Bloch MH, Panza KE, Yaffa A, et al.: N-Acetylcysteine in the treatment of pediatric Tourette syndrome: Randomized, double-blind, placebo-controlled add-On trial. J Child Adolesc Psychopharmacol. 2016, 26:327-34.10.1089/cap.2015.0109

4. Wink LK, Adams R, Wang Z, et al.: A randomized placebo-controlled pilot study of Nacetylcysteine in youth with autism spectrum disorder. Mol Autism. 2016, 7:26.

10.1186/s13229-016-0088-6

5. Hardan AY, Fung LK, Libove RA, et al.: A randomized controlled pilot trial of oral Nacetylcysteine in children with autism. Biol Psychiatry. 2012, 71:956-61.

10.1016/j.biopsych.2012.01.014

6. Ghanizadeh A, Moghimi-Sarani E: A randomized double-blind placebo-controlled clinical trial of N-Acetylcysteine added to risperidone for treating autistic disorders. BMC Psychiatry. 2013, 13:196. 10.1186/1471-244X-13-196

7. Nikoo M, Radnia H, Farokhnia M, et al.: N-acetylcysteine as an adjunctive therapy to risperidone for treatment of irritability in autism: A randomized, double-blind, placebocontrolled clinical trial of efficacy and safety. Clin Neuropharmacol. 2015, 38:11-7. 10.1097/WNF.0000000000000063

8. Dean OM, Gray KM, Villagonzalo KA, et al.: A randomised, double-blind, placebo-controlled trial of a fixed dose of $\mathrm{N}$-acetyl cysteine in children with autistic disorder. Aust $\mathrm{N} \mathrm{Z}$ J Psychiatry. 2017, 51:241-49. 10.1177/0004867416652735

9. American Psychiatric Association: Diagnostic and Statistical Manual of Mental Disorders (4th 
Edition), Text Revision. American Psychiatric Association, Washington DC; 2000.

10. Franklin ME, Flessner CA, Woods DW, et al.: The child and adolescent trichotillomania impact project: descriptive psychopathology, comorbidity, functional impairment, and treatment utilization. J Dev Behav Pediatr. 2008, 29:493-500. 10.1097/DBP.0b013e31818d4328

11. Kratochvil CJ, Bloch MH: Trichotillomania across the lifespan. J Am Acad Child Adolesc Psychiatry. 2009, 48:879-83. 10.1097/CHI.0b013e3181ae09f3

12. Grant JE, Odlaug BL, Kim SW: N-acetylcysteine, a glutamate modulator, in the treatment of trichotillomania: A double-blind, placebo-controlled study. Arch Gen Psychiatry. 2009, 66:756-63. 10.1001/archgenpsychiatry.2009.60

13. Bloch MH, Panza KE, Grant JE, et al.: N-Acetylcysteine in the treatment of pediatric trichotillomania: A randomized, double-blind, placebo-controlled add-on trial. J Am Acad Child Adolesc Psychiatry. 2013, 52:231-40. 10.1016/j.jaac.2012.12.020

14. Rothbart R, Amos T, Siegfried N, et al.: Pharmacotherapy for trichotillomania . Cochrane Database Syst Rev. 2013, 10.1002/14651858.CD007662.pub2

15. Odlaug BL, Grant JE: N-acetyl cysteine in the treatment of grooming disorders . J Clin Psychopharmacol. 2007, 27:227-9. 10.1097/01.jcp.0000264976.86990.00

16. Ghanizadeh A, Derakhshan N, Berk M: N-acetylcysteine versus placebo for treating nail biting, a double-blind randomized placebo-controlled clinical trial. Antiinflamm Antiallergy Agents Med Chem. 2013, 12:223-8. 10.2174/1871523011312030003

17. Roten AT, Baker NL, Gray KM: Marijuana craving trajectories in an adolescent marijuana cessation pharmacotherapy trial. Addict Behav. 2013, 38:1788-91.

10.1016/j.addbeh.2012.11.003

18. Roten AT, Baker NL, Gray KM: Cognitive performance in a placebo-controlled pharmacotherapy trial for youth with marijuana dependence. Addict Behav. 2015, 45:119-23. 10.1016/j.addbeh.2015.01.013

19. McClure EA, Baker NL, Gray KM: Cigarette smoking during an N-acetylcysteine-assisted cannabis cessation trial in adolescents. Am J Drug Alcohol Abuse. 2014, 40:285-91. 10.3109/00952990.2013.878718 